\title{
La retórica homoerótica en dos poemarios de Carlos Pellicer
}

\author{
Gerardo Bustamante Bermúdez \\ Universidad Autónoma de la Ciudad de México \\ gerardbb81@hotmail.com
}

\begin{abstract}
Resumen: Dentro de la prolífica obra lírica de Carlos Pellicer, los poemarios Hora de junio (1937) y Recinto y otras imágenes (1941) ocupan un lugar especial porque presentan elementos textuales, simbólicos e intertextuales para apoyar la tesis de que se trata de poemarios que revelan el tema amoroso entre varones, pero sobre todo, el tópico del "amor secreto". En el presente artículo se analizan los elementos simbólicos que permiten dilucidar la construcción de una poética homosexual en Pellicer, sobre todo porque el uso de la lítote y de pronombres impersonales permiten al poeta la construcción de su amor disidente y secreto que apenas se atreve a nombrar en una época en la que la experiencia homoerótica no es visible ni se corresponde con la noción que el estado posrevolucionario tiene de la masculinidad.
\end{abstract}

PALABRAS ClaVE: poesía; homoerotismo; amor; secreto; soledad.

Aвstract: Within the prolific work of Carlos Pellicer, poetry books Hora de junio (1937) and Recinto y otras imágenes (1941) occupy a special place because they present textual, symbolic and intertextual elements to support the thesis that are poems that reveal the theme of love between men, but especially the topic of "secret love". In this paper symbolic elements that allow elucidate the construction of a homosexual poetic in Pellicer are analysed, especially because the use of understatement and impersonal pronouns allows the poet to build his dissenting secret love, that he doesn't dare to name at a time when homoerotic experience is not visible and doesn't correspond to the notion that the postrevolutionary state has of masculinity.

KEYWORDS: Poetry; homoeroticism; love; secrecy; solitude.

FeCHA DE RECEPCión: 8 de enero de 2015

FeCHA DE ACEPTACIÓN: 8 de mayo de 2015

¿Adónde te escondiste,

Amado, y me dejaste con gemido?

Como el ciervo huiste,

habiéndome herido,

sali tras ti clamando, y ya eras ido.

San Juan de la Cruz 
Fn La literatura mexicana del siglo XX (1995) de José Luis Martínez la tendencia vanguardista de los escritores del grupo Contemporáneos
locisto fue posible gracias al impulso educativo y cultural generado alrededor de José Vasconcelos en la Secretaría de Educación. Esta generación homogénea de artistas reunidos alredor de la revista que le da nombre al grupo (1928-1931) la componen Carlos Pellicer, Salvador Novo, Xavier Villaurrutia, Bernardo Ortiz de Montellano, Jorge Cuesta, Jaime Torres Bodet, Elías Nandino y José Gorostiza. El grupo, considerado por varios críticos como un nuevo Ateneo de la Juventud tuvo una corta vida como tal, pero cimentó las bases para la publicación de textos diversos de poesía, teatro, prosa, crítica de arte y traducciones. También fue un intento sólido que más tarde se diversificó en publicaciones de gran importancia para la cultura literaria en México, como es el caso de Examen, Metáfora, Fábula, Estaciones y otras en las que varios de estos escritores participaron como hacedores o colaboradores.

Carlos Pellicer Cámara (1897-1977), de acuerdo con José Luis Martínez y Christopher Domínguez, posee una leyenda particular, sobre todo por su fervor bolivariano, su gusto por el trópico, la selva y las culturas prehispánicas. Asunto nodal en su poesía es el sentido religioso, particularmente la admiración franciscana, así como los paisajes y naturaleza de Latinoamérica. Para referirse a Recinto y otras imágenes (1941), Martínez y Domínguez señalan el tema amoroso, la pérdida y la emoción memorable. Ninguna referencia al tema del amor homosexual y a la experiencia de desdicha que en el contexto biográfico el autor padecía al momento de escribir su propia crónica amorosa.

La obra de Carlos Pellicer ha sido ampliamente estudiada. Con los años, abundan estudios serios, tesis e incluso se han publicado los epistolarios del autor o de otros escritores que permiten conocer la formación intelectual, artística y política del tabasqueño: Correspondencia (1918-1928). José Gorostiza y Carlos Pellicer (1999); Correspondencia entre Carlos Pellicer y Germán Arciniegas (2002), edición de Serge I. Zaïtzeff; Epistolario (1918-1940), edición de Guillermo Sheridan, que recopila la correspondencia de José Gorostiza con otros tantos personajes, entre ellos, Pellicer; Cartas de la gran Gabriela Mistral a Carlos Pellicer, libro también compilado por Zaïtzeff; Correspondencia (1925-1959). Carlos Pellicerl Alfonso Reyes (2000), preparado por Zaïtzeff. A pesar de que en varias cartas de juventud Pellicer cuenta algunos episodios 
amorosos con jovencitas, lo que deja ver en poemarios como Recinto y otras imágenes es una identidad sexual performativa en el autor, quien a través de la omisión de nombres e incluso de pronombres gramaticales sugiere una identidad sexual heterodoxa.

En Protagonistas de la literatura mexicana, Pellicer conversa con Emmanuel Carballo y refiere que Hora de junio (1937) es un poemario que relata su desastre amoroso y, bajo reserva, advierte: "Sólo puedo decirle que [los poemas de Hora de junio] son consecuencia de un fracaso sentimental. Un fracaso más que le importa a un poeta. Les tengo cariño porque son una herida abierta permanentemente. Han pasado muchos años y la herida no se cierra" (245). Además, sobre el contexto de producción de Recinto y otras imágenes, afirma: "Allí cuento una historia de amor que se cumplió de cabo a rabo. De esos poemas hay algunas cosas apreciables, más apreciables por lo humano que por lo poético. El amor, poéticamente, fuera de la Vita nuova y de algunos sonetos italianos e ingleses (de Shakespeare) no existe. Me asombra leer poesía amatoria escrita a base de suburbios poéticos" (245). La conversación entre Carballo y Pellicer se llevó a cabo en 1962, pero ni el entrevistador ni el entrevistado dan pistas claras respecto a la identidad sexual del sujeto aludido tanto en Hora de junio como en Recinto y otras imágenes. Se trata de una conversación que afirma sólo el contexto de la pérdida amorosa, pero desde la indefinición de la persona gramatical. Por lo anterior, revisar la retórica en la poesía amorosa de Pellicer resulta sustantivo en un contexto en el que los estudios de género y literarios han abonado a la discusión y visibilidad de identidades alternativas a la heterosexualidad. La entrevista de Carballo sólo evoca el tema amoroso, pero como afirma Carlos Monsiváis al cuestionar el poema "Recinto": "¿Para una pareja heterosexual sería arriesgado besarse, oprimirse las manos, mirarse demasiado, callar en buena lid?” (183). ¿Cómo debemos interpretar los lectores la poesía de Recinto y otras imágenes cuando la voz poética pide cerrar las puertas para estar a solas con los besos del sujeto amado, en una habitación que resguarda la pasión y los cuerpos de dos enamorados que se besan, se miran y se oprimen las manos?

Del grupo de escritores homosexuales de Contemporáneos, son Xavier Villaurrutia, Carlos Pellicer y Elías Nandino quienes establecen una poética del amor secreto, aquel que sólo se puede confesar con reservas, a veces con claves y cuya visibilidad homosexual sólo está presente en los códigos que utiliza el poeta para dejar velado su amor. El tema de 
la censura, el secreto y la mirada social pueden ser revelados a partir de lo que evocan en el lector, pues una atenta lectura permite desentrañar condiciones adversas para la voz lírica, pues desde lo social hay señalamientos y comentarios que censuran e impiden la confesión plena. A decir de Sergio Téllez-Pon:

A lo largo de todos los sonetos de Hora de junio, es claro que al referirse a junio como el sexto mes del calendario Pellicer se las ingenia para nombrar de esa manera al amado. También, mientras en Hora de junio Pellicer mantiene el tono característico de gran parte de su poesía (el de la luz, la flora, la fauna, el trópico), en Recinto, y en especial en el "Nocturno", es extraño leerlo en ese tono apesadumbrado, elegiaco. Es, con estos poemas, cuando más se acerca a las poéticas de los Contemporáneos y por eso a veces, no sólo por amistad, se le liga a ese grupo (111).

La crítica literaria ha denostado el análisis homoerótico en la poesía de Carlos Pellicer; sin embargo, el llamado poeta de América tiene en su haber dos libros que nos permiten analizar su identidad sexual heterodoxa, su amor gozoso y sufriente, que a veces, en medio de un paisaje idílico pide un beso a su amado, pero en ocasiones, el estado de soledad hace que el poeta se aísle y quede únicamente en la espera dolorosa del olvido. ¿Cuál es la manera de analizar el corpus poético homoerótico de Pellicer, cuáles son las condiciones contextuales, formalistas y semánticas que nos permiten analizar ciertos poemas del autor desde la retórica amatoria homosexual? Si la intención primaria de la crítica literaria es la de interpretar desde la enunciación misma del texto, entonces podemos decir que existen marcas en los poemas de Pellicer que nos permiten saber que se refiere a un amor homosexual, sobre todo porque enmascara de forma muy cuidada la referencia a la persona gramatical. El crítico literario, a decir de Mario Valdés, es un intérprete que explica su comprensión de una obra literaria a partir del texto mismo, así como del contexto histórico de producción. A partir de la interpretación lo que se pretende es la discusión de ese lenguaje artístico a veces privado e incluso indescifrable. En ocasiones, dice Valdés, "leer es realizar la fusión de la competencia lingüística del lector en el discurso del texto. Esta acción confiere a la lectura la capacidad de renovación del texto en cada nueva lectura y confiere también al texto su apertura polisémica" (326). En aras de comprender la retórica homoerótica de Pellicer, conviene anali- 
zar las imágenes que evocan la relación homoerótica presente, aunque de forma secreta, en la obra del poeta tabasqueño.

En su texto "El arte como artificio", el formalista ruso Shklovski plantea que la poesía a través del lenguaje de las imágenes supone una manera de pensar y conocer, pues "el carácter estético de un objeto, el derecho de vincularlo a la poesía, es el resultado de nuestra manera de percibir" (57). Así, para el autor existen dos tipos de imágenes en el discurso: 1) la que es un medio práctico de pensamiento que pertenece al espacio de lo literal; 2) la imagen poética, que es un medio de refuerzo de la reimpresión y que pertenece al terreno de la poesía. Si la imagen poética es un medio para crear una expresión máxima del espíritu, entonces conviene desentrańar lo que el poeta pretende comunicar a través de la creación artística, pues,

la finalidad del arte es dar una sensación del objeto como visión y no como reconocimiento; los procedimientos del arte son los de la singularización de los objetos, y el que consiste en oscurecer la forma, en aumentar la dificultad y la duración de la percepción. El acto de percepción es en el arte un fin en sí y debe ser prolongado. El arte es un medio de experimentar el devenir del objeto; lo que ya está "realizado" no interesa para el arte (60).

Si las imágenes poéticas que sugiere Pellicer sobre el tema homosexual deben interpretarse desde el terreno del lenguaje que construye su visión singular de la experiencia amorosa, entonces hay que comenzar por decir que la publicación de Hora de junio corresponde a una época en la que el psicoanálisis explica desde el terreno médico, jurídico y social las conductas y clasificaciones sobre la homosexualidad, pero sobre todo, a través del inconsciente, con sus correspondientes subjetividades. Hay que señalar que la ciencia médica y mental responden también a los intereses de las políticas de Estado en Occidente y a la instauración de las políticas sexogenéricas de corte binario. Confesar plenamente su amor homosexual y su experiencia amorosa resulta imposible en una época en la que Freud plantea en varios textos la categorización de las llamadas "desviaciones sexuales". En su texto "Tres ensayos para una teoría sexual" (1910), el autor clasifica en tres categorías la conducta de los "invertidos", según el criterio de lo "normal" como condición única y aceptable dentro de los parámetros freudianos. 
a) Invertidos absolutos: su objeto sexual tiene necesariamente que ser de su mismo sexo, no siendo nunca del sexo opuesto el de su deseo sexual, sino que los deja fríos o despierta en ellos manifiesta repulsión sexual. Los invertidos absolutos masculinos son, en general, incapaces de realizar el acto sexual normal o no experimentan placer alguno al realizarlo.

b) Invertidos anfígenos: (hermafroditas psicosexuales); esto es, su objeto sexual puede pertenecer indistintamente a uno y otro sexo. La inversión carece, pues, aquí de exclusividad.

c) Invertidos ocasionales: bajo determinadas condiciones exteriores - en las cuales ocupan el primer lugar la carencia de objeto sexual normal y la imitación- pueden adoptar como objeto sexual a una persona de su mismo sexo y hallar satisfacción en el acto sexual con ella realizado (1173).

Hay que señalar, además, que será hasta 1974 cuando la homosexualidad queda desclasificada de los manuales de enfermedades psiquiátricas. Las décadas de los treinta y cuarenta en México todavía explican los binarismos sexogenéricos a partir de los postulados freudianos que se corresponden con la instauración de la política judeocristiana de amplia difusión en Occidente. Por lo anterior, el tópico del amor secreto en la poesía de autores como Xavier Villaurrutia, Elías Nandino y Carlos Pellicer es apenas un secreto, un susurro que manifiesta los estados de felicidad, soledad o anhelo amoroso del sujeto masculino escondido o apenas velado en los versos de los poemas. Agréguese, además, que en el caso de Pellicer, su filiación vasconcelista y su compromiso como poeta e intelectual de América son también un impedimento que le pesa al escritor para actuar de una forma mucho más abierta en el discurso, similar a la de Salvador Novo, por ejemplo.

A decir de Carlos Monsiváis, dentro de la producción pelliceriana, los poemarios Hora de junio y Recinto y otras imágenes son el conjunto de poemas de amor más armonioso de la literatura mexicana:

En vida de Pellicer, la discreción sobre la orientación sexual es obligada y las alusiones a la heterodoxia amorosa son escasas ("De callar este amor que es de otro modo"). Desde la perspectiva actual, se entiende ya de un modo más abierto el otro amor, que todavía hace unas décadas dice su nombre como puede. Pellicer, muy libre en su conducta, incapaz de 
fingimientos, se niega a la amargura y el desencanto, y en lugar de la frustración elige la felicidad del amor posible al que legitima, por encima de las convenciones de la época, el acuerdo entre dos personas (en Pellicer 2003a: 15).

Precisamente es desde la actualidad que los estudios de género y particularmente aquellos que tratan sobre masculinidades diversas permiten un abordaje del corpus de poemas del autor tabasqueño que dan cuenta de su amor homosexual.

Hora de junio está compuesto por 24 poemas, cinco de ellos llevan el nombre de "Horas de junio" y se construyen por estrofas de entre 8 y 12 endecasílabos, con rima abrazada. Es precisamente a partir de la eficacia de la rima que en el nivel fónico se aprecia la armonía que se genera en el ambiente natural y amoroso referido por el poeta. La propuesta de ir alternando estos poemas del mismo nombre entre otros permiten al lector hacer una pausa para, después, continuar la especie de narrativa lírica que plantea Pellicer respecto a su sentir amoroso. Con esta sección de poemas vemos cómo la voz autoral confiesa que su poema nace a partir de una ilusión en ese jardín de junio que le entrega la voz/ inspiración, pero también la soledad y el dolor por una relación que da por perdida. Junio posee un doble valor semántico, pues por una parte alude al mes significativo de la experiencia amorosa/dolorosa, pero también puede entenderse como el número seis de doce que tiene el año, es decir, hablar de mitad o igualdad significa una forma de nombrar el amor en masculino. Junio puede ser el sustantivo masculino que le da Pellicer a su amado.

En los poemas "Horas de junio" hay un estado de pesadumbre alrededor del poeta debido al amor ausente que lo ha dejado sólo con la palabra que él materializa en la poesía: espina y rosa son dos elementos opuestos que se quedan en las sensaciones del poeta. Él contempla al objeto (rosa) que está en las alturas, en cambio, a su nivel sólo puede tener acceso a las espinas, como alusión al dolor que le dejó el desdén de quien se ausentó: "Si algo hay en mí que valga es la amargura / de un desdeñado vaso de dulzura / que una noche lluviosa está secando" (2003b: 244). Sin embargo, estos poemas titulados de manera homónima dan cuenta del cambiante estado de ánimo del poeta en el terreno amoroso. Algo ha sucedido en la narrativa del yo lírico que nos plantea escenarios diferentes: a veces pasa de la plegaria amorosa a la desolación, 
luego muestra realización afectiva para enseguida sentir que el amor con el sujeto referido no es posible. Lo que presenta Pellicer en estos cinco poemas es el estado cambiante de la experiencia amorosa. La condición de amor/felicidad tiene también el ingrediente del desamor/llanto; anhelo/desesperación. En medio de una recreación de elementos de la naturaleza, el poeta pide la presencia de su figura amada ausente y para guardar secreto sobre la identidad, exclama:
¡Cuánto tardas allí, cosa lejana!
Veo y busco tu faz de monte a monte.
Nivelé el corazón al horizonte
y está en mi mano cual una manzana (252).

Cuando el poeta ofrece su corazón a la persona amada lo hace constantemente en el contexto de un ambiente con "nubes", palabra que se repite casi en todos los poemas titulados "Horas de junio". Las nubes - a veces se usa el singular - pueden ser luminosas u obscuras, según los estados anímicos de la voz lírica. El Diccionario de los símbolos de Chevalier dice que la nube revela una naturaleza confusa, incognoscible. La nube envuelve, cubre y no permite ver con claridad al espectador, que en el contexto de Pellicer sería el lector. Aunque la nube se asocia a un contexto celeste, "se vincula con el símbolo del agua y, en consecuencia, de la fecundidad [...] La nube es el símbolo de la metamorfosis vista, no en uno de sus términos, sino en su propio devenir" (757). La nubosidad sirve para proteger de las miradas ajenas a la historia de dos, pero también el poeta manifiesta que en ocasiones las nubes son sinónimo de peligro, sobre todo porque le impiden ver la presencia de su sujeto amado.

Debido a la saturación de elementos naturales en los poemas titulados "Horas de junio" (nubes, noche, monte, rosa, brisa, viento, agua, cosmos, etcétera), el poeta crea en el lector un efecto sinestésico que envuelve los estados idílicos, de contemplación o desolación que le provoca al poeta ese junio en la memoria.

Para referir de manera velada su amor homosexual, el poeta recurre a la expresión "idénticos anhelos" para afianzar la noción de mismidad o semejanza: "Energía de idénticos anhelos / que aleja y avecina y que los mece, / juntó en choque de fuerzas luz que acrece / la sombra en tierra de sus hondos cielos" (2003b: 257-258). El yo lírico utiliza las 
figuras retóricas de la antítesis y el oxímoron cuando plantea el amor no correspondido, aquel que se le esconde entre las nubes ${ }^{1}$ y lo deja contemplando su soledad, como lo hace saber en el quinto poema de los que titula "Horas de junio", en donde de forma velada le habla al "amor" como sentimiento generado en el poeta, pero también puede interpretarse como la voz de un yo-masculino que le habla a un tú, también masculino.

Amor así, tan cerca de la vida, amor así, tan cerca de la muerte. Junto a la estrella de la buena suerte la luna nueva anúnciate la herida.

En un cielo de junio la escondida noche te hace temblar pálido y fuerte;

el abismo creció por conocerte robando al riesgo su sorpresa henchida (257).

El quinto poema titulado "Horas de junio" es a mi juicio el que manifiesta mayores marcas respecto al sujeto masculino destinatario: el poeta asume que los dos eran "materia de los cielos", es decir, algo irrevelado. En este poema algunos versos revelan la identidad masculina: "En un cielo de junio la escondida / noche te hace temblar pálido y fuerte" (257); "Ya estás herido por mi propia suerte / y somos la catástrofe emprendida / con todo nuestro ser desnudo y fuerte" (257); "Energía de idénticos anhelos" (257). La noción de fuerza generalmente está asociada al espacio de lo masculino, además, el poeta escribe "pálido", pero no se refiere a junio como el sexto mes del año, sino a un sujeto masculino. Cuando dice que su interlocutor está "herido" no hay posibilidad de anfibología poética. Por su parte, la expresión "idénticos anhelos" supone desde la subjetividad del poeta la revelación mascarada de las identidades sexuales de los dos involucrados, pues la revisión de estos cinco poemas manifiesta que no siempre el sujeto amado experimenta el anhelo, de ahí la desazón o tristeza del poeta.

\footnotetext{
${ }^{1}$ En ocasiones el poeta también permanece como espectador de un cielo que le impide ver a ese amante encubierto por nubes.
} 
Por otra parte, las manos del poeta ofreciendo su corazón o su dolor a su interlocutor se convierten en una imagen que funciona a manera de anáfora por el sentido de la repetición del ofrecimiento. También se usa de forma permanente la metonimia al mostrar su ofrenda (corazón en las manos) al amante; uno y otro están en una dialéctica no correspondida: "Salgo de ti y estoy en tu tristeza, / sales de mí y estás en tu belleza. / Las estrellas nos ven: ya hay otro mundo" (258).

Los poemas intitulados "Horas de junio" permiten conocer el estado placentero/idílico y angustiante del poeta inmerso en esa nubosidad que revela o esconde la presencia del destinatario/interlocutor. En Hora de junio Pellicer no abandona la idea de la naturaleza como partícipe y espectadora del sentir del yo lírico. En gran medida la presencia de otros poemas más contemplativos de paisajes americanos lo acercan a sus primeros trabajos literarios y lo vinculan incluso a la estética romántica y modernista, particularmente a la de poetas como Salvador Díaz Mirón, Amado Nervo, José Martí o Rubén Darío. Con los cinco poemas titulados "Horas de junio" Pellicer apenas se acerca al tema de la confesión velada; todavía tendremos que esperar cuatro años más para conocer con mayor detalle un poemario que posee más elementos para pensar en el tema homoerótico, pero que corresponde a la época de escritura de los años treinta, pues varios de los poemas de Recinto y otras imágenes se escribieron entre 1930 y 1931 y algunos corresponden incluso a una etapa anterior de escritura de los escritos para Hora de junio. Lo interesante de la escritura de Recinto y otras imágenes es preguntarnos por qué su autor esperó diez años para publicar aquellos poemas que dan muestra de una poética homoafectiva/homoerótica. Si bien es cierto que el poema "Elegía nocturna" está fechado en 1939 y "Nocturno" en 1940, éstos pueden leerse como una suerte de corolario a la historia de amor/desamor que cierra el poeta, al menos en el terreno de la escritura.

Recinto y otras imágenes es una colección de poemas que se ocupan del tema del amor, el deseo y las realizaciones homoeróticas, la mayoría de las veces apenas veladas. El libro está dedicado al escritor sinaloense Genaro Estrada (1887-1937) y tiene un epígrafe del propio Pellicer en el que asienta los tópicos del Bien y el Mal que entran por los ojos y se albergan en el alma. Con este epígrafe se sugiere la idea del posible juicio moral de los lectores del poemario, además de que desde el epígrafe se advierte la presencia de los ojos, propios o ajenos como una constante del poemario. 
Sobre el contenido velado en la poesía de Pellicer, Raúl Leiva aduce que el poemario es "poesía frutal, paradisíaca, donde el sol es rey, porque Pellicer maneja las palabras con una luz cuyo secreto sólo a él le pertenece" (388). Sin embargo, las tonalidades del poemario van dando cuenta de los encontrados estados amorosos que goza/sufre el poeta, de ahí que podemos considerar que este poemario es una crónica amorosa que presenta su amor a veces luminoso, pero a veces oscuro y en ese sentido las nociones de Bien/Mal; confesión/secreto; oscuridad/ luz plantean escenarios similares a los practicados por Federico García Lorca en Sonetos de amor oscuro, poemario del poeta granadino que vio la luz hasta 1995. En su ensayo "La poesía de Carlos Pellicer", Leiva afirma con acierto que se trata de una

poesía sensual y exaltada que deja en nosotros su olor real, su sabor de fruta madura, su huella telúrica. Poesía musical, donde los ritmos se sumergen en nosotros con una suave o violenta cadencia; poesía que toca nuestra piel con su tacto sutil, electrizante; poesía material, corpórea, viviente, llena de volúmenes, de gracia, de redondeces impensadas [sic]. El poeta que alguna vez confesó ser "un poco de sol desnudo" ha sabido vibrar con lo más puro y noble de nuestros pueblos en lucha independentista $(378-379,384)$.

Lo que el crítico señala es el compromiso social con los pueblos americanos que plantea Pellicer en su libro Piedra de sacrificios, publicado en 1924, con prólogo de José Vasconcelos, pero también sugiere que la condición homosexual de Pellicer no lo aleja del compromiso social, por eso afirma que el "secreto" sólo le pertenece a él. La mirada del poeta está en los paisajes de la naturaleza americana, pero también en la exploración de su interior, por eso confiesa sus idilios, estados angustiantes, depresiones y desprendimientos amorosos. Este poemario está dividido en dos partes: "Recinto" y "Otras imágenes". La primera se ocupa enteramente de esa mirada y confesión interior que al materializarse en un poema dividido en veinte cantos pone al descubierto su disidencia sexual, pues el poeta con frecuencia tiene miedo y reserva en que sean precisamente las miradas de los otros las que descubran su amor. La segunda corresponde a asuntos de exaltación de paisajes como Oaxaca o Peñíscola. También se trata de poemas dedicados a personalidades como Luis Barragán, Diego Rivera, Efraín Huerta, Eduardo Villaseñor 
y Margarita Quijano. ${ }^{2}$ Para los fines de la exploración del tema amoroso y homosexual, las secciones de "Recinto" son particularmente las que se ocupan de la crónica biográfica del amor/desamor del poeta, que va pasando de una experiencia idílica y contemplativa a una enteramente desoladora. Es en esta sección en la que el uso de los siguientes sustantivos adjetivados permiten ver el afán del poeta por enmascarar la identidad sexual de su ser amado: esperada persona, ser amado, adorada persona (se usa en dos ocasiones), persona sedienta, el nombre sin nombre..., dulce criatura. Seis sustantivos que si los conectamos con la simbología de junio como el sexto mes del calendario, se traducen desde la noción de mismidad o igualdad sexual del yo lírico con el destinatario.

Recinto es una palabra polisémica en el contexto del poema de Pellicer, pues puede aludir al lugar sagrado que guarda el poeta en el corazón y en la mente, pero también puede ser el espacio de encuentro secreto entre los amantes y que es el templo de su amor. Una tercera interpretación del vocablo podría ser aquella que nos haga pensar que el "recinto" es el cuerpo del ser amado. La Real Academia Española define el vocablo "recinto" de la siguiente manera: "(Del lat. re y cinctus, cercado, rodeado). 1. Espacio comprendido dentro de ciertos límites" (1913). A través de su poesía, es el poeta quien cerca, rodea los límites de su espacio amatorio. Si en otros poemarios de Pellicer se habla de una amplia extensión de espacios, sobre todo de aquellos en los que se ocupa de la naturaleza americana, en "Recinto" el espacio se cierra, pide la intimidad; lo cerca a través de la palabra. El recinto dentro de la simbología de las religiones es un espacio sagrado, "guardado y defendido por constituir una unidad espiritual" (Cirlot: 382). Su crónica de amor/ dolor Pellicer la coloca en un lugar especial de su escritura, en un cerco en donde los demás no pueden acceder, de ahí también que la noción del "amor secreto" o apenas velado sea parte de la poética del cerco que el autor construye alrededor de un lenguaje no directo. El recinto es considerado en la mitología una imagen del cielo; remite a lo circular y cerrado, por eso, "el cerco es el símbolo de la reserva sagrada, del lugar infranqueable, salvo para el iniciado" (Chevalier: 875). En cualquiera de sus formas, lo que hace el poeta es hacer y escribir un poema humano que tiene rostro e historia dentro de su línea biográfica. Es a través del

${ }^{2}$ Son precisamente los poemas dedicados a dichas personalidades los que hacen que el libro tenga también otra lectura más allá de la crónica biográfica y amorosa del autor. 
cuidado del lenguaje y del uso de la lítote como figura retórica en donde el poeta dice más a partir de lo que calla o apenas sugiere.

Los veinte poemas de la sección "Recinto" pueden leerse como una crónica amatoria que va dando muestra del estado idílico, la duda, la espera, la sensualidad, la realización amorosa, la desesperación, la soledad y el dolor. Se trata de una crónica lírica en la que el poeta declara que interrumpe su práctica escritural cotidiana para centrar su atención en la vivencia amorosa: "Antes que otro poema / tome la ciudadela a fuego y ritmo, / yo te digo, callando, / lo que el alma en los ojos dice sólo" (2003b: 275-276). Ese sujeto indefinido, evocado como el "ser amado" o la "adorada persona" en la parte I de "Recinto", va teniendo presencia absoluta en el presente de la enunciación. En la parte II del poema, el yo lírico pide la intimidad de la alcoba; pide que se cierre la puerta, quien en su exterior expone las miradas de los otros, los que no pueden ver ese amor secreto. La mirada aparece nuevamente como un personaje más del poemario; es a través de ella que se juzga el bien y el mal, lo moral y lo inmoral, por eso, la habitación y la puerta cerradas pueden resguardar la intimidad de lo prohibido por la moral heteronormativa:

Que se cierre esa puerta

que no me deja estar a solas con tus besos.

Que se cierre esa puerta

por donde campos, sol y rosa quieren vernos.

Esa puerta por donde

la cal azul de los pilares entra

a mirar como nińos maliciosos

la timidez de nuestras dos caricias

que no se dan porque la puerta, abierta...

Por razones serenas

pasamos largo tiempo a puerta abierta.

$\mathrm{Y}$ arriesgado es besarse

y oprimirse las manos, ni siquiera

mirarse demasiado, ni siquiera

callar en buena lid... (276).

Esta sección II de "Recinto" es la que plantea el tema amatorio desde la sensualidad. Una vez que el exterior (puerta abierta) hace visible la 
presencia de los amantes sólo como amigos, el poeta pide la intimidad con su "ser amado". En el día la puerta permanece abierta para evitar las interpretaciones, pero por la noche la puerta "se cierra tan ciega" y da paso al encuentro dulce entre la pareja. El poeta acaricia con la fuerza de sus brazos el torso de su amante. La puerta cerrada da una tregua al encuentro que obstruye el ingreso de los intrusos y permite "la liberación de estas dos cárceles; / la escapatoria de las dos pisadas / idénticas que saltan a la nube / de la que se regresa en la mañana” (277). Las "idénticas pisadas" supone también la referencia al mismo sexo y el saltar hacia la nube significa colocarse transitoriamente en un nivel superior (altura) respecto de la tierra. La nube se asocia a las aguas superiores, pero también a la "metamorfosis, que esconde la identidad perenne de la verdad superior" (Cirlot: 333). La verdad se encuentra entre las cuatro paredes de la habitación, en donde con su producción poética, el yo lírico disuade a su interlocutor, lo conquista con poemas sobre la naturaleza. Después, en la parte III viene el silencio, la imagen de los cuerpos juntos, descansando de forma placentera, idílica: "Yo tengo / tu cabeza en mi pecho. Todo cuaja / la transparencia enorme de un silencio / panorámico, terso, / apoyado en el pálido delirio / de besar tus mejillas en silencio" (2003b: 278).

Dentro del hilo narrativo que propone la crónica amatoria de "Recinto", en el apartado IV hay un cambio de escenario, pues ya se plantea la idea del recuerdo y la ausencia de esa "sedienta persona". El poeta manifiesta su anhelo cuando dice: "Este amor que ascendimos y doblamos / para ocultar lo oculto que ocultamos" (279). El tiempo que avanza queda marcado por la presencia de la expresión "activos brazos del estío”, que alude al periodo del solsticio entre el verano y el otońo. El poeta calibra los recuerdos, pero la desazón viene en la parte $V$ cuando manifiesta que la ausencia de su amada persona lo encarcela:
Ya no sé caminar sino hacia ti, ni escuchar otra voz que aquella noble voz que del vaho borde de la dicha vuela para decirme las palabras que azogaron el agua del poema (279).

La noción de lo acuoso (metáfora de la vida y la fertilidad) va desapareciendo del poema para convertirse en sequedad paulatina; en aban- 
dono, sobre todo a partir de la sección XI del poema. No obstante, dentro de la historia amorosa, podemos observar que la parte IV plantea un retorno breve de la figura amada que vuelve a darle dicha y luz al poeta, quien pide: " $i$ Ten piedad / de nuestro amor y cuídalo, oh, vida!" (280). En la sección V nuevamente hay una ausencia y el poeta susurra el nombre de su amado "sin que nadie lo escuche". La memoria se torna tormentosa a partir de la sección VII porque en medio de un paisaje natural, casi pastoril, el autor contrasta la belleza natural con el fingimiento de los ojos errantes de la persona amada que ya no voltean a mirar el "recinto" idílico. Pellicer habla de un fingimiento amoroso por parte de su interlocutor, de una historia fugaz, breve como el junio de nubes que encumbró el verano. Hay un sentimiento empático de la naturaleza —elemento del Romanticismo que retoma el autor-, que a través de la personificación, se conduele de la condición sufriente y de abandono en el que está postrado el sujeto lírico:

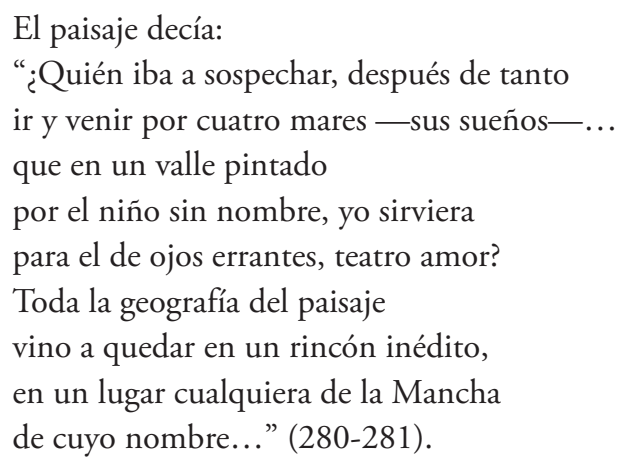

El fingimiento de la persona amada, la simulación o la teatralidad hacen contraste con la naturaleza empática en la que el poeta se ve rodeado. La intertextualidad a manera de cita que hace Pellicer con el inicio de El ingenioso hidalgo Don Quijote de la Mancha, de Cervantes Saavedra, tiene por una parte la intención de no evocar una memoria tormentosa, pero también la de omitir el nombre de la persona amada que se pretende olvidar, según reza en su propio contexto la obra de Cervantes.

Como parte de la crónica de la experiencia homoerótica, en las partes VIII-X de "Recinto" el poeta confiesa existir a partir de la presencia del otro; el poema se vuelve sensitivo porque habla de ambientes, olores, 
tacto y gusto. La mirada sigue siendo un elemento presente en el poema; el yo lírico abre el espacio a la naturaleza, contempla la belleza del paisaje y mira también su condición de abandonado en el presente como en el pasado, pues Pellicer enuncia un fracaso amoroso previo. En la sección VI, dice: "Otros soles no dieron sino ocasos, / sino puertas sin dueño, soledades" (280). Y en la sección X refiere sobre sí: "de la resurrección de la ceniza / por las derrotas de otros días” (283).

Las evocaciones sensitivas, la memoria de esa sensualidad de la "persona amada" de la que el poeta habla al evocar su olor, los besos y el "deleite sin fin" concluye en la sección X. El dolor pleno inicia a partir de la sección XI, pues el idilio ha concluido y el poema adquiere un tono apesadumbrado, oscuro; la naturaleza es grisácea. El poeta deja de entregarse a su memoria evocativa; se sabe solo; ya no tiene interlocutor más allá del espacio escritural de la poesía: "La primera tristeza ha llegado. Tus ojos / fueron indiferentes a los míos" (284). Lo que antes era una historia placentera, ahora se advierte como el silencio de "frutos podridos". Lo acuoso (vida) se modifica en lágrimas del poeta (dolor); la nube se torna oscura y en la sección XII el espacio se cierra a la soledad del poeta como consecuencia de la ausencia. La crónica del llanto vuelve a tomar forma de recuerdo en las secciones XIII-XIV en donde se manifiesta la añoranza, el recuerdo y la lejanía física y emocional de la persona amada. El contexto de soledad en el poeta se torna en silencio, a la vez que escritura y conciencia sobre su condición de hombre que sólo cuenta con la palabra poética para evocar sensaciones y recuerdos. Bajo el tópico del amor secreto, en el poema XV titulado con mayúsculas "FIN DEL NOMBRE AMADO", el poeta escribe:
Un soneto de amor que nunca diga de quién y cómo y cuándo, y agua dé a quien viene por noticia y en sí lea clave caudal que sin la voz consigna (287).

$\mathrm{Al}$ poeta le interesa preguntarse si la amada persona recordará las caricias. Imagina al otro y se pregunta si lo recordará cuando en las calles otros rostros o labios se lo evoquen. Sobre el espacio cerrado (recinto) que fue testigo y cómplice de su amor, dice en el siguiente cuarteto del poema XVI: 
¿Y si al pasar frente a la casa abierta alguien adentro grita: ¡Carlos!?

¿Habrá en tu corazón el buen latido?

¿Cómo será el acento de tu paso? (288).

El poeta también afirma que su poema "abre camino al alma del objeto / que adoro y cuyo nombre dicen todos" (287). ¿Quién es esa persona? ¿Cuál es su identidad y qué lugar ocupó en la vida del poeta como para ser presencia en una composición de largo aliento que cuenta la crónica del amor/desamor; del idilio que se convierte en llanto, soledad y escritura? En su artículo "Carlos Pellicer y Germán Pardo García”, León Guillermo Gutiérrez afirma que Recinto y otras imágenes corresponde a la historia de amor entre el tabasqueño y el joven poeta colombiano. Respecto al tema de lo que aquí he llamado el "tópico del amor secreto", Gutiérrez encuentra que ya aparece el sentimiento de culpa religiosa por su homosexualidad en el joven Pellicer en los poemas "Mi corazón es viejo y está herido" (1916) y "Nocturno patético" (1917). La revisión de epistolarios que hace el crítico le permite hilar la relación de estos dos escritores y documentarla. ${ }^{3}$

Sobre la progresión temporal de la crónica amatoria que se convierte en agonía, algunos poemas de Recinto y otras imágenes nos sugieren que en junio da inicio el idilio del poeta, pero el apartado XVIII habla de septiembre: "Sé del fruto maduro de las voces / en campos de septiembre" (290). Luego, en la sección "Otras imágenes”, Carlos Pellicer le dedica a su amigo un poema titulado "Al poeta colombiano Germán Pardo García", en donde menciona el mes de octubre y, además, habla de un

\footnotetext{
${ }^{3}$ Para mayor información sobre la documentación epistolar, véase Gutiérrez 2013. En el estudio preliminar de Correspondencia entre Carlos Pellicer y Germán Arciniegas, Serge I. Zaïtzeff menciona que Carlos Pellicer llega a Bogotá hacia finales de 1918 en su carácter de representante de la Federación de Estudiantes de México y se quedará hasta febrero de 1920 con el fin de promocionar los valores culturales de México, propugnados por el gobierno de Venustiano Carranza. Es en Bogotá que el tabasqueño conoce a Germán Pardo García y Germán Arciniegas. En las cartas a Germán Arciniegas, que van del 26 de enero de 1920 al 20 de agosto de 1956, se menciona el nombre de Pardo García once veces, pero en realidad no hay ningún tipo de confesión que los involucre en un romance, sino información de carácter académico y artístico o envío de saludos a través de Arciniegas.

${ }^{4}$ Germán Pardo García (1902-1991) fue un periodista y poeta que vivió en México durante 1931, año que se corresponde con la escritura de Recinto y otras imágenes. Pelli-
} 
"cielo amistad" que los une. Los dos tercetos del poema sin duda resultan reveladores porque el poeta obsequia a su amigo el cielo mexicano. ¿Acaso son las nubes que los ocultaban en junio? ¿Es Germán Pardo García la inspiración poética de Pellicer y el destinatario de la sección "Recinto"? El poema es muy claro:

Germán, toma este cielo mexicano que de un ángulo empuño hasta tu mano y te lo doy joctubre azul, tuyo y tan mío!

Siento la poesía y sin nombrarla pienso en ti. Sola está. Sólo el rocío puede, como tus manos, despertarla (318).

Si la poesía está sola, entonces la presencia de Pardo García puede reactivar la escritura en Pellicer. Aunque el poema está fuera de la sección "Recinto", resulta interesante cuestionar por qué el poeta no lo incluyó en la sección, o bien, por qué no excluyó la parte "Otras imágenes" de su poemario. Hay sin duda una conexión temática, a pesar de colocarlo en la segunda parte del libro, posiblemente para no evidenciar la relación dentro de la línea biográfica de "Recinto". Los siguientes versos son incluso más reveladores porque al hablar de "este amor que es de otro modo" notamos que si la felicidad, el anhelo, la contemplación, el placer e incluso el dolor son condiciones inherentes al amor mismo — sin etiquetas de género- entonces no hay razón para clasificar ese amor como algo que está fuera de la norma, es decir, todos los sentimientos y experiencias que escribe Pellicer en su poemario están presentes en cualquier tipo de relación heterosexual. En la tercera estrofa del poema XVIII, que cierra con puntos suspensivos, se lee:

Sé de la noche esbelta y tan desnuda que nuestros cuerpos eran uno solo.

cer ya le había dedicado el poema "Melodía en fa", perteneciente a 6, 7 poemas (1924), con la dedicatoria "A Germán Pardo García, en Colombia”, por lo que queda claro que no están juntos. Entre 1925 y 1929 Pellicer se encuentra en Europa. Será hasta 1931 que se dé el reencuentro, cuando el colombiano llega a México y se hospeda en la casa de la familia Pellicer. 
Sé del silencio ante la gente oscura, de callar este amor que es de otro modo... (290).

La historia y la experiencia amorosa de Pellicer se vuelven confusas respecto a las contradicciones sentimentales del enamorado, pues cuando parece que el retorno del amado es imposible, en los poemas XIX y $\mathrm{XX}$, escritos en forma de soneto, el poeta vuelve a manifestar un nuevo estado de ilusión; opta por el silencio como manifestación del temor a quedarse solo; acepta sin cuestionar el regreso de su interlocutor, quien en poemas anteriores, había "huido":

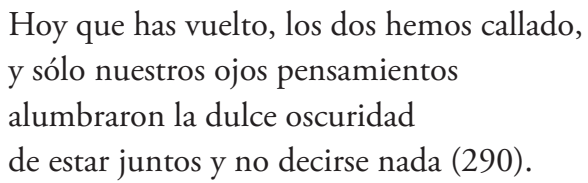

De la sección "Otras imágenes" hay algunas conexiones temáticas que se pueden hacer con la crónica amatoria de "Recinto". Hay en esta sección cuatro poemas que llevan por nombre "Estudio". El primero de ellos sí posee marcas en masculino. El poeta habla de un deseo de estar al lado de la otra persona en medio de la naturaleza feliz. En la segunda estrofa expone las marcas en masculino, sobre todo por el juego fonético de la paronomasia que se hace entre Eros, el dios del amor y el sexo y el verbo "ser" en pretérito imperfecto, referente a la segunda persona del singular. Hay también una conexión con la metáfora de los hombres navegantes (marinos) a los que el poeta les quita la marca cultural de lo masculino cuando apuesta por una androginia:

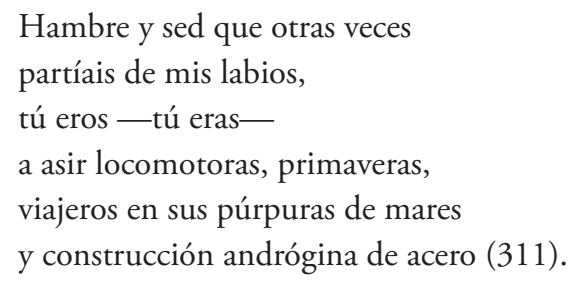

La cuarta estrofa del mismo poema introduce el sujeto "Hambre", pero le da calificativos en masculino: "Hambre; tú estás siempre desnudo, / casi invisible, fuerte, hermoso, / insaciable de ti, como el es- 
pejo, / como el espejo, eterno" (311). El espejo, que aparece en tres ocasiones en poemas de la sección "Recinto", refiere la simbología de la mismidad, pero también de la presencia caleidoscópica del amante, en el sentido de que aparece y desaparece. Cuando desaparece, al poeta le queda la imaginación, el recuerdo, pero también la conciencia de la discontinuidad y la imposibilidad del diálogo.

Por otra parte, resulta significativo que Pellicer vuelva a titular un poema "Horas de junio", tal como lo hizo en el poemario de 1937. En esta ocasión se trata de un tema desarrollado y dividido en tres sonetos en donde el poeta recuerda las horas idílicas de junio, manifiesta nuevamente ilusión y declara a esa amada persona: "el alma te esperó, siempre te espera" (317). La segunda estrofa del primer soneto que compone "Horas de junio" revela el sustantivo en masculino a la vez que hace uso del encabalgamiento como figura de dicción entre los versos 1 y 2 :
Busco y te hallo, profunda y efusiva
gracia viril que nube tan terrena
rasó el área jardín tu voz morena
y llueve rubio tras la luz festiva (316).

Líneas arriba se dijo que junio corresponde al sexto mes del año en el que inicia el idilio del poeta, así que recordar ese mes/historia representa dentro de la ilusión del enamorado poeta una suerte de regresar al paisaje cómplice, al menos en el terreno del recuerdo. Se trata de un tiempo cíclico, de otro junio que se repite en la evocación. En el tercer soneto que compone el poema, la voz lírica le habla directamente al mes, no al sujeto amado. En este poema mira al junio pasado de manera menos pesimista, aunque sigue manifestando su necesidad de amor humano, por eso, con el florecimiento de la ilusión, el poeta le habla en el segundo terceto a una "dulce creatura" aún indeterminada: "Ven a mi corazón, dulce creatura, / y verás, por el viento que lo mece, / la flor doblada y herida en la altura" (317). Desde mi interpretación, el sustantivo adjetivado "flor doblada" se refiere al espíritu del poeta que ve su vida como algo ya perecedero, pues se encuentra doblado, es decir, arruinado.

Sin duda, los tres últimos poemas de la sección "Otras imágenes" plantean el estado desolador y resignando de un poeta que ha perdido toda ilusión y sólo le queda el lamento. "Elegía nocturna" es un poema 
que desde el título enuncia el carácter fúnebre del espíritu del poeta rechazado no sólo por la "amada persona", sino por esa otra "dulce creatura" indeterminada que no llegó a suplir al ausente. El poema está compuesto por cuatro sonetos, fechados por el autor en diciembre de 1939. Son nueve años después de ese junio idílico, pero el dolor no ha desaparecido. Como su nombre lo indica, la hora nocturna es propicia para que el poeta recuerde. En medio del llanto, la soledad y la desesperanza, Pellicer diserta sobre el pasado, le sigue interesando saber si está en el pensamiento del amado. En los cuatro sonetos que componen la elegía, el poeta hace uso de la anáfora para acentuar su sentimiento de hombre rechazado:

Ay de mi corazón que nadie quiso

tomar entre mis manos desoladas.

Tú viniste a mirar sus llamaradas

y le miraste arder claro y sumiso (322).

El uso del nocturno, forma poética tan explorada en la poesía mexicana del siglo xx, principalmente por los autores de Contemporáneos, le sirve al poeta para afianzar su idea apesadumbrada alrededor de una vida que siente como severa. El recurso de la queja y la manifestación de su desdicha amorosa finaliza con el poema de verso libre titulado "Nocturno" que se advierte como un testamento poético de su renuncia al idilio y al amor. El poema tiene un tono eminentemente amargo, fatalista. El corazón que él ofreció entre sus manos ya no es enunciado. Ahora sólo le escribe a "aquellos que han pasado la vida mirando la dicha de otros" (326) y lo hace a través de la anáfora. El poeta le escribe el nocturno apesadumbrado a aquellos que han gritado, llorado su propia soledad y, como él, aceptado el "destino" trágico de tres mil años atrás. El uso de la hipérbole sirve para enunciar el dolor propio y el de los que, como él, se colocan como espectadores de la dicha ajena. Pellicer cierra su crónica amatoria con la solidaridad hacia los dolidos:

Aquellos que saben como yo de la gran soledad, conocerán la profunda amargura del tren del poema que dice el horror de la horrible belleza que así significa la vida severa y heroica de una esperanza de pronto-por siempre desierta 
Recinto y otras imágenes es la crónica amatoria que se vuelve naufragio, pesadumbre y soledad. Al final, sólo le queda al poeta el recurso de la escritura para materializar lo que en su memoria siente con hondo dolor. Lo que el poeta le confesó a Emmanuel Carballo a finales de los ańos sesenta es esa historia de amor que signa en el poeta el sentimiento de tragedia amorosa. El poemario es un libro valiente, a pesar de que el poeta recurre a la mascarada y al tópico del "amor secreto". En él no sólo existen marcas textuales y simbólicas que permiten saber que se trata de una historia amorosa entre dos hombres, sino que el poeta deja su testimonio como testamento de una época; cuando pide que se cierre la puerta lo hace con el anhelo frenético que excluye la intromisión de los moralistas, pero al final, el poema "Nocturno" enfatiza que él mismo ha decidido cerrar esa puerta porque ya no ofrece ese corazón entre sus manos que nadie quiso recibir.

\section{BibliografíA}

Carballo, Emmanuel. "Carlos Pellicer", en Protagonistas de la literatura mexicana, México: Alfaguara, 2005: 237-262.

Chevalier, Jean y Alain Gheerbrant. Diccionario de los simbolos. Traducción del francés a cargo de Manuel Silver y Arturo Rodríguez. Barcelona: Herder, 2012.

Cirlot, Juan Eduardo. Diccionario de simbolos. Barcelona: Siruela, 2014.

Diccionario de la lengua española. Madrid: Espasa, 2003.

Freud, Sigmund. “Tres ensayos para una teoría sexual”, en Obras II (19051915). España: Biblioteca Nueva, 2007: 1173-1214.

Gutiérrez, León Guillermo. “Carlos Pellicer y Germán Pardo García”, en Amerika (2013). Artículo en línea: <http://amerika.revues.org/4006 ;DOI:10.4000/amerika.4006>. Fecha de consulta: 12 de noviembre de 2014.

Martínez, José Luis y Christopher Domínguez Michael. La literatura mexicana del siglo XX. México: Conaculta, 1995 (Cultura Contemporánea de México).

Pellicer, Carlos. Correspondencia entre Carlos Pellicer y Germán Arciniegas. Edición de Serge I. Zaïtzeff. México: Conaculta (Memorias Mexicanas), 2002.

Pellicer, Carlos. Iconografía. Presentación de Carlos Monsiváis. México: Fondo de Cultura Económica, 2003a (Tezontle). 
Pellicer, Carlos. Obras. Poesía. Edición de Luis Mario Schneider. México: Fondo de Cultura Económica, 2003b (Letras Mexicanas).

Leiva, Raúl. "La poesía de Carlos Pellicer”, en Estaciones. Revista Literaria de México. Año 2, núm. 8, invierno de 1957: 378-395.

Monsivárs, Carlos. "De la marginalidad sexual en América latina. Hay día en que somos tan lúbricos, tan lúbricos", en Que se abra esa puerta. Crónicas y ensayos sobre diversidad sexual. México: Paidós / Debate Feminista, 2010.

Shklovski, Víktor. "El arte como artificio", en Teoría de la literatura de los formalistas rusos. Antología preparada y presentada por Tzvetan Todorov. Traducción del ruso a cargo de Ana María Nethol. México: Siglo XXI, 2007: 55-70 (Crítica Literaria).

TÉllez-Pon, Sergio. "La fuerza oculta del otro amor. La poesía homoerótica”, en Michael K.Schuessler y Miguel Capistrán (coords.). México se escribe con J. Una historia de la cultura gay. México: Planeta, 2010: 101117 (Temas de Hoy).

VAldés, Mario. “Sobre la interpretación”, en Marc Angenot et al. (dir.). Teoría literaria. Traducción del francés de Isabel Vericat Núñez. México: Siglo XXI Editores, 2002: 317-330 (Lingüística y Teoría Literaria). 